\title{
Seasonal growth variation in Chlamys islandica (Bivalvia) from sub-Arctic Greenland is linked to food availability and temperature
}

\author{
Martin Emil Blicher ${ }^{1,2, *}$, Søren Rysgaard ${ }^{1}$, Mikael K. Sejr ${ }^{2}$ \\ ${ }^{1}$ Greenland Climate Research Centre, Greenland Institute of Natural Resources, Kivioq 2, 3900 Nuuk, Greenland \\ ${ }^{2}$ National Environmental Research Institute, University of Aarhus, Vejlsøvej 25, 8600 Silkeborg, Denmark
}

\begin{abstract}
In order to assess the role of different environmental parameters in the population dynamics of marine invertebrates in the Arctic, we examined seasonal variation in individual biomass, shell growth, and mass production of somatic and reproductive tissues of immature and maturing scallops Chlamys islandica suspended in culture nets at 15 and $30 \mathrm{~m}$ depth in SW Greenland from May 2007 to October 2008. All 3 parameters varied both seasonally and between depths. Individual shell growth rate and biomass were poor proxies for the actual mass growth rate on a seasonal scale. Minimum and maximum mass growth rates were observed from November to February and in April-May, respectively. Simultaneous monitoring of biotic and abiotic parameters in the water column made it possible to establish a growth model relating variation in mass growth rate to variation in environmental conditions. The best-fit model $\left(R^{2}=0.71\right)$ indicated that total mass growth rate depended on chlorophyll a concentration, carbon-to-nitrogen ratio of seston, and water temperature. While availability of high-quality food items affected growth positively, the growth model indicated a negative effect of increasing temperature on the mass growth rate of $C$. islandica. These results indicate that scallops in SW Greenland are resource-limited and that elevated temperature through its effect on metabolic costs reduces growth efficiency. Hence, it is most likely that the growth capacity of $C$. islandica in SW Greenland is either never realized or only attained for short periods of time (hours to days) under the present conditions.
\end{abstract}

KEY WORDS: Bivalve $\cdot$ Scallop $\cdot$ Temporal dynamics $\cdot$ Production $\cdot$ Food availability $\cdot$ Sub-Arctic Pectinid $\cdot$ Temperature $\cdot$ Shell growth

Resale or republication not permitted without written consent of the publisher

\section{INTRODUCTION}

The strong seasonality in the Arctic is known to be a major component affecting the life cycles and survival strategies of animals at all trophic levels (e.g. Conover \& Huntley 1991, Heide-Jorgensen et al. 2003, Rysgaard \& Nielsen 2006). However, studies of temporal variation in the structure and function of the marine ecosystem in the Arctic are relatively few. Partly due to the logistical challenges in Greenland, long-term monitoring programs covering all seasons have not been initiated until recently (www.G-E-M.dk), resulting in little knowledge of the coupling between environmental variation and ecological characteristics in this region. Benthic macrofauna has been recognized as important for carbon cycling in the Arctic marine ecosystem (e.g. Grebmeier et al. 2006, Sejr \& Christensen 2007). Still, very little is known about the relation between benthic population dynamics and the seasonality of their habitat.

Reduction of the seasonal sea ice cover (spatial extent, duration, and thickness) and increased freshwater input from land are direct consequences of the ongoing warming of the Arctic (Peterson et al. 2002, Johannessen et al. 2004, Hanna et al. 2008, Lindsay et al. 2009, McPhee et al. 2009). Both factors have the potential to directly or indirectly affect the magnitude and the seasonal dynamics of marine primary produc- 
tion (Rysgaard et al. 1999, 2003, Dagg et al. 2004, Wassmann et al. 2006, Arrigo et al. 2008), potentially leading to altered food conditions for secondary producers. Low temperature is considered an important component of high-latitude marine environments, affecting physiological rates of ectotherms at all trophic levels (Gillooly et al. 2001). Thus, it might be expected that future changes in ocean temperature and food availability in the Arctic will affect the productivity of secondary producers (Blicher et al. 2007). However, the combined effect may not be straightforward. Hence, it is still debated whether the apparent temperature-dependence of the basal metabolism of ectotherms is solely a consequence of thermodynamics, or if the processes involved in metabolism have been subject to evolutionary adaptation to maximize production in a given environment, i.e. maximizing the difference between energy intake and metabolic costs (e.g. Clarke \& Johnston 1999, Gillooly et al. 2001, Clarke 2003). In any case, it seems likely that the effect of increasing temperature on organism growth is dependent on the ability of an organism to compensate for the elevated metabolic cost of maintenance through increased energy assimilation. This ability is likely to differ between taxa, functional groups, and life styles, but is ultimately dependent on resource availability (Clarke 2003, Clarke \& Fraser 2004). This is in accordance with Harrington (1987), who suggested that a latitudinal cline in growth of the venerid bivalve genus Protothaca in the NE Pacific was related to the length of the period during which individuals could feed.

Feeding experiments have indicated that the filterfeeding bivalve Hiatella arctica from high-Arctic NE Greenland is resource-limited in its natural environment and is highly capable of increasing energy assimilation in response to increased phytoplankton concentrations despite temperatures $<0^{\circ} \mathrm{C}$ (Sejr et al. 2004). In another study compiling all previously published estimates of pectinid metabolic rates across latitudes, a relation between mean ambient temperature (range: 0 to $25^{\circ} \mathrm{C}$ ) and standard metabolic rate was established, demonstrating a $Q_{10}$ of 2.97 , thus indicating tight coupling to temperature. However, temperature did not explain variations in growth performance, suggesting decreased growth efficiency with increasing temperature (Heilmayer et al. 2004). Still, Heilmayer et al. (2005) argued that growth rates of juvenile Antarctic scallops Adamussium colbecki were positively affected by temperature; unfortunately, however, their study did not take into account the potential role of food.

Another filter-feeding bivalve, the scallop Chlamys islandica, is a circumpolar species occurring in coastal areas and fjords off the entire west coast of Greenland (Pedersen 1994). It is regarded as an ecologically important species (Blicher et al. 2009). Feeding experiments in northern Norway have indicated that seston composition can affect the absorption efficiency of $C$. islandica, and thus potentially influence the growth rate of this species (Vahl 1980). Moreover, oxygen consumption in actively feeding specimens did not relate to ambient temperature in a laboratory study (Vahl 1978), indicating that other factors, such as food availability, are potential key drivers of metabolic activity, as suggested for Antarctic sea urchins (Brockington \& Clarke 2001). The objective of the present study was to describe the variation in individual production of $C$. islandica suspended in cages in the field, in relation to seasonal and spatial variation in temperature, salinity, and food availability in a sub-Arctic fjord. We hypothesized that, on a seasonal scale, bivalve growth was resource-limited. However, if bivalves were not limited by food availability the alternative hypothesis was that temperature, through its effect on physiological rates and filtering capacity, affected growth positively.

\section{MATERIALS AND METHODS}

Experimental setup. Chlamys islandica specimens were collected using a triangular dredge in the outer Kobbefjord, SW Greenland, at 50 to $60 \mathrm{~m}$ depth in May 2007 (Fig. 1). After collection, bivalves were immediately transferred to containers with aerated seawater. Scallops were then tagged individually with numbered shellfish tags $(4 \times 8 \times 0.15 \mathrm{~mm}$, Hallprint) on the upper shell (Ross et al. 2001). Tags were attached near the shell margin with a cyanoacrylate adhesive after dabbing the shell dry with a towel. Shell heights (SH) of all specimens were measured with digital callipers to the nearest $0.01 \mathrm{~mm}$, and the scallops were divided into 2 initial size groups, representing: (1) immature (15 $\leq$ $\mathrm{SH} \leq 35 \mathrm{~mm})$, and (2) maturing bivalves $(35<\mathrm{SH} \leq$ $55 \mathrm{~mm}$ ) (Blicher et al. 2009), and transferred to lantern box nets (FUKUI type, Coastal Aquacultural Supply) with tiers of $0.2 \mathrm{~m}^{2}$ each and $12 \mathrm{~mm}$ mesh size. We allowed scallops to cover no more than $25 \%$ of the tier area, i.e. a maximum of 10 and 20 individuals per tier for size groups 2 and 1 , respectively, which was similar to the densities observed in the natural environment (Blicher et al. 2009). A total of 752 scallops, equally represented by the 2 size groups, were tagged. Lantern nets were deployed in the outer part of the Godthåbsfjord (Fig. 1) using anchors and buoys to keep the lanterns suspended $5 \mathrm{~m}$ above the sea floor (Narvarte 2003). Each of the 2 size groups was suspended at 2 different depths, 15 and $30 \mathrm{~m}$, respectively. Thus, we analysed 4 separate groups, differing in size and/or deployment depth. Obviously, the sizes of the scallops changed during the experiment due to 


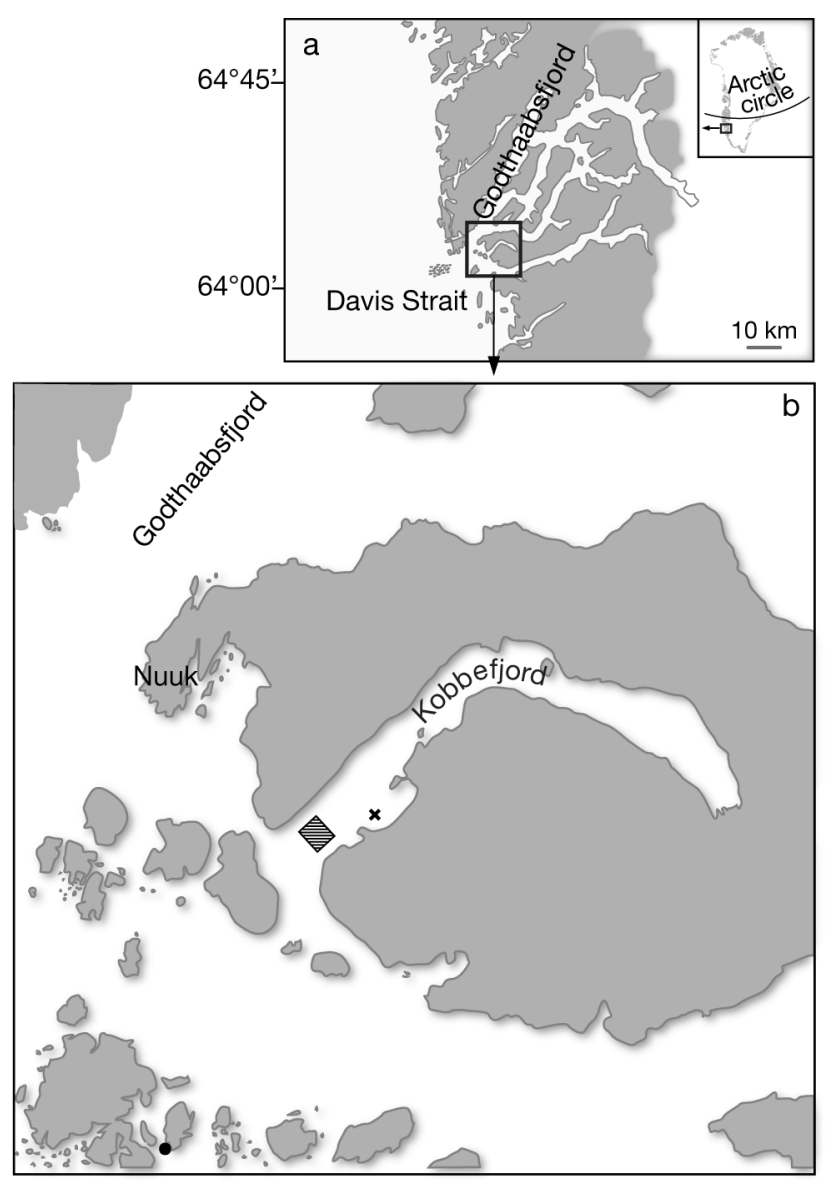

Fig. 1. (a) Location of the study site in Greenland. (b) Hatched area in the outer part of Kobbefjord indicates the site of collection of Chlamys islandica. The initial deployment site is indicated by $\mathbf{x}$ is the location in Kobbefjord to which scallops were transferred after being suspended for $2.5 \mathrm{mo}$

growth, but in the text we use the terms Group 1 and Group 2 to refer to the initial SH size groups of the scallops. In the beginning of August 2007 we moved the lantern nets to Kobbefjord (Fig. 1) for reasons explained in 'Results - Environmental parameters'.

Sampling and calculations. After an initial recovery period of $\sim 2.5 \mathrm{mo}$, we measured $\mathrm{SH}$ of each tagged scallop at approximately monthly intervals until the end of the experiment in October 2008. Scallops were carefully retrieved from the lantern nets and placed in aerated sea water at ambient temperature, after which SH was measured quickly using digital callipers before individuals were placed in the lantern nets again. Thus, for each individual we were able to calculate the average shell growth rate, $G_{\mathrm{s}}\left(\mathrm{mm} \mathrm{d}^{-1}\right)$, in any given monthly period:

$$
G_{\mathrm{s}}=\frac{\mathrm{SH}_{2}-\mathrm{SH}_{1}}{\Delta t_{12}}
$$

where $\mathrm{SH}_{1}$ and $\mathrm{SH}_{2}$ are individual $\mathrm{SH}(\mathrm{mm})$ at times 1 and 2 , respectively, and $\Delta t_{12}$ is the number of days between times 1 and 2. In order to establish a general shell growth function, size increment data (SID) for a complete seasonal cycle, from August 2007 to August 2008, were fitted to a modified specialized von Bertalanffy growth model (Brey 2001):

$$
\mathrm{SH}_{2}=\mathrm{SH}_{1}+\left(\mathrm{SH}_{\infty}-\mathrm{SH}_{1}\right)\left(1-\exp \left(-K \Delta t_{12}\right)\right)
$$

where $\mathrm{SH}_{\infty}$ is the asymptotic $\mathrm{SH}(\mathrm{mm}), K$ is a growth coefficient $\left(\mathrm{d}^{-1}\right)$, and $\Delta t_{12}$ is the number of days from August $2007\left(t_{1}\right)$ to August $2008\left(t_{2}\right)$. The first derivative of the specialized von Bertalanffy model is equal to the predicted daily shell growth rate, $\hat{G}_{\mathrm{s}}\left(\mathrm{mm} \mathrm{d}^{-1}\right)$, at $\mathrm{SH}$ :

$$
\hat{G}_{\mathrm{s}}=K \times \mathrm{SH}\left(\frac{\mathrm{SH}_{\infty}}{\mathrm{SH}}-1\right)
$$

The ratio between the observed individual shell growth rate, $G_{\mathrm{s}}$ and the predicted shell growth rate, $\hat{G}_{\mathrm{s}}$ in a given period during the year was regarded as an index of shell growth rate, $\mathrm{GI}_{\mathrm{s}}$ :

$$
\mathrm{GI}_{\mathrm{s}}=\frac{G_{\mathrm{s}}}{\hat{G}_{\mathrm{s}}}
$$

At each sampling date we sub-sampled 10 specimens from each size group and depth for the analysis of biomass. Immediately after sampling, we carefully dissected the scallops into gonad and somatic tissue (adductor muscle, digestive gland, mantle, and gills). Dry mass (DM) was determined by drying at $60^{\circ} \mathrm{C}$ for $72 \mathrm{~h}$. In order to obtain a general relation between $\mathrm{SH}$ and DM we fitted biomass-at-size data obtained from a total of 13 sampling dates through a period of $17 \mathrm{mo}$ to the allometry equation:

$$
\log _{\mathrm{e}}\left(\mathrm{DM}_{\text {pred }}\right)=a+b \log _{\mathrm{e}}(\mathrm{SH})
$$

Where $\mathrm{DM}_{\text {pred }}$ is the predicted DM, $a$ is the intercept, and $b$ is the slope. The general relations between (1) $\mathrm{SH}$ and gonad mass, $\mathrm{DM}_{\text {gonad, }}$ (2) $\mathrm{SH}$ and somatic mass, $\mathrm{DM}_{\text {somatic, }}$ and (3) $\mathrm{SH}$ and total tissue mass, $\mathrm{DM}_{\text {total }}$ were used to calculate individual index values for biomass, BMI:

$$
\mathrm{BMI}=\frac{\mathrm{DM}_{\mathrm{obs}}}{\mathrm{DM}_{\text {pred }}}
$$

where $\mathrm{DM}_{\mathrm{obs}}$ is the observed individual $\mathrm{DM}$, and $\mathrm{DM}_{\text {pred }}$ is the DM predicted from Eq. (5). Average BMI (BMI) was calculated for each of 4 sub-samples (dependent on initial size and depth) at any given sampling date. This approach was based on the assumption of a common coefficient, $b$ (Eq. 5) for all seasons. ANCOVA models containing the predictor variables $\mathrm{SH}$ (covariate) and sampling date (categorical), and the interaction term $\mathrm{SH} \times$ sampling date, were used to test for seasonal variation in the relation between $\mathrm{SH}$ and BMI (somatic, gonad, and total). We estimated instan- 
taneous individual mass growth rates, $G_{\mathrm{m}}\left(\mathrm{d}^{-1}\right)$, in the period between sampling dates by combining $(\overline{\mathrm{BMI}})$ values with changes in individual $\mathrm{SH}$ :

$$
G_{\mathrm{m}, 12}=\frac{\operatorname{Ln}\left[\frac{\mathrm{DM}_{\text {pred }} \times \overline{\mathrm{BM}}_{i(2)}}{\mathrm{DM}_{\text {pred }} \times \overline{\mathrm{BM}}_{i(1)}}\right]}{\Delta t_{12}}
$$

Where $G_{\mathrm{m}, 12}$ is the mass growth rate in the period between time 1 and time 2. DM pred is estimated from the observed individual $\mathrm{SH}$, and $\left(\overline{\mathrm{BMI}}_{i(1)}\right)$ and $\left(\overline{\mathrm{BMI}}_{i(2)}\right)$ are average BMI at times 1 and 2, respectively, and $i$ refers to the 4 combinations of depth $(15,30 \mathrm{~m})$ and size group (1 and 2).

We wanted to be able to study the effect of key environmental drivers on the seasonal growth variation of scallops independent of potential differences in individual $\mathrm{SH}$ and changes in $\mathrm{SH}$ (due to growth) during the study period. A general function describing the effect of $\mathrm{SH}$ on the instantaneous mass growth rate, including a more sophisticated approach to variance, made it possible to remove any size dependence of our estimates of seasonal growth variation. Thus, we prevented any bias of the results caused by differences in $\mathrm{SH}$ between groups or changes in $\mathrm{SH}$ within groups during the 17 mo study period. Overall, the procedure ensured that data could be compared across the relevant spatial and temporal scales. This normalization of our data is described below:

The combined $G_{\mathrm{m}}$ at $\mathrm{SH}$ data (somatic, gonad, and total, respectively) were fitted to an exponential model:

$$
\hat{G}_{\mathrm{m}}=a \times \exp (b \times \mathrm{SH})
$$

where $\hat{G}_{\mathrm{m}}$ is the predicted mass growth rate at size $\mathrm{SH}$, and $a$ and $b$ are coefficients in the model. An error term, $\varepsilon$, was considered, such that

$$
G_{m}=\hat{G}_{m}+\varepsilon
$$

where $G_{m}$ is the actual mass growth rate. $\varepsilon$ is assumed to be normally distributed with zero mean and a power relationship between its variance and $\mathrm{SH}$ :

$$
\varepsilon=N\left\{0,\left(q \mathrm{SH}^{z}\right)^{2}\right\}
$$

where $q$ and $z$ define the variance. This is a flexible expression of variance, which implies potential heteroscedasticity. However, the expression contains, and can easily be collapsed to, the common simple forms, e.g. $z=0$ gives homoscedastic errors, $z=1$ gives standard deviation (SD) proportional to SH. Parameters were fitted by maximizing the joint likelihood of the $\varepsilon$ values, $\ln (1)$ (e.g. Lebreton et al. 1992).

The size-dependent mass growth data were normalized to a mass growth index, $\mathrm{GI}_{\mathrm{m}}$, by dividing the observed deviation from the predicted mass growth rate with the modelled SD (Eq. 10), also known as a standard score (Larsen \& Marx 2005):

$$
\mathrm{GI}_{\mathrm{m}}=\frac{G_{\mathrm{m}}-\hat{G}_{\mathrm{m}}}{q \mathrm{SH}^{z}}
$$

$\mathrm{GI}_{\mathrm{m}}=0$ is equal to the predicted mass growth rate, while $\mathrm{GI}_{\mathrm{m}}= \pm 1$ means that the difference between the observed and the predicted mass growth rate equals \pm 1 SD. Average $\mathrm{GI}_{\mathrm{m}}\left(\overline{\mathrm{GI}}_{\mathrm{m}}\right)$ was calculated for each of 4 groups (dependent on initial size and depth) for any given sampling period. The present study was specifically focused on producing comparable estimates of seasonal growth rates independent of size, which involved this rather complex process of normalization. However, values of $\mathrm{GI}_{\mathrm{m}}$ could easily be back-calculated to the more commonly used absolute mass growth rates; a calculation that provides the opportunity to describe in detail how size affects the ability to maintain a positive energy balance in different seasons.

Environmental parameters. Temperature was registered every $6 \mathrm{~h}$ at each culturing depth throughout the experimental period using temperature loggers (HOBO U22 Water Temp Pro v2, Onset Computer Corporation) mounted on each of 2 lantern nets. Approximately every 2 wk we took water samples with a Niskin-type sampler (KC-Denmark) for the analysis of photosynthetic pigments, and particulate carbon and nitrogen at the specific site and depth. This was supplemented with CTD casts (SBE 19+, Sea-Bird Electronics) specifically to measure salinity and generally to get a better spatial understanding of water column properties at the site.

Seawater samples from 15 and $30 \mathrm{~m}$ depth were filtered (Whatman GF/C, $<0.2$ bar) for determination of chlorophyll a (chl a). The filters were extracted in $96 \%$ ethanol for $18 \mathrm{~h}$ in the dark. After extraction, the samples were analysed on a Turner Designs TD-700 fluorometer. Chl a in the samples was calculated in accordance with Parsons et al. (1984).

Total particulate carbon (TPC) and nitrogen (PON) were measured on water samples filtered onto Whatman GF/C filters. After filtration the samples were dried at $60^{\circ} \mathrm{C}$ for $24 \mathrm{~h}$ and stored separately until analysis on an elemental analyser (ANCA-GSL, SerCon).

Coupling of growth to environmental variation. The total $\overline{\mathrm{GI}}_{\mathrm{m}}$ data set was used to construct a growth model relating environmental parameters (chl $a$, TPC, $\mathrm{C}: \mathrm{N}$, temperature, salinity, chl a:TPC, and interaction terms) to mass growth rate. Environmental parameters were averaged by interpolating linearly between data points, as illustrated in Fig. $2 \mathrm{a}-\mathrm{e}$, and dividing the integrated area between each scallop sampling by the number of days in the given periods. In this way, the estimates of $\mathrm{GI}_{\mathrm{m}}$ and environmental variables represented the same time intervals. The model selection process was based on minimizing the Akaike informa- 

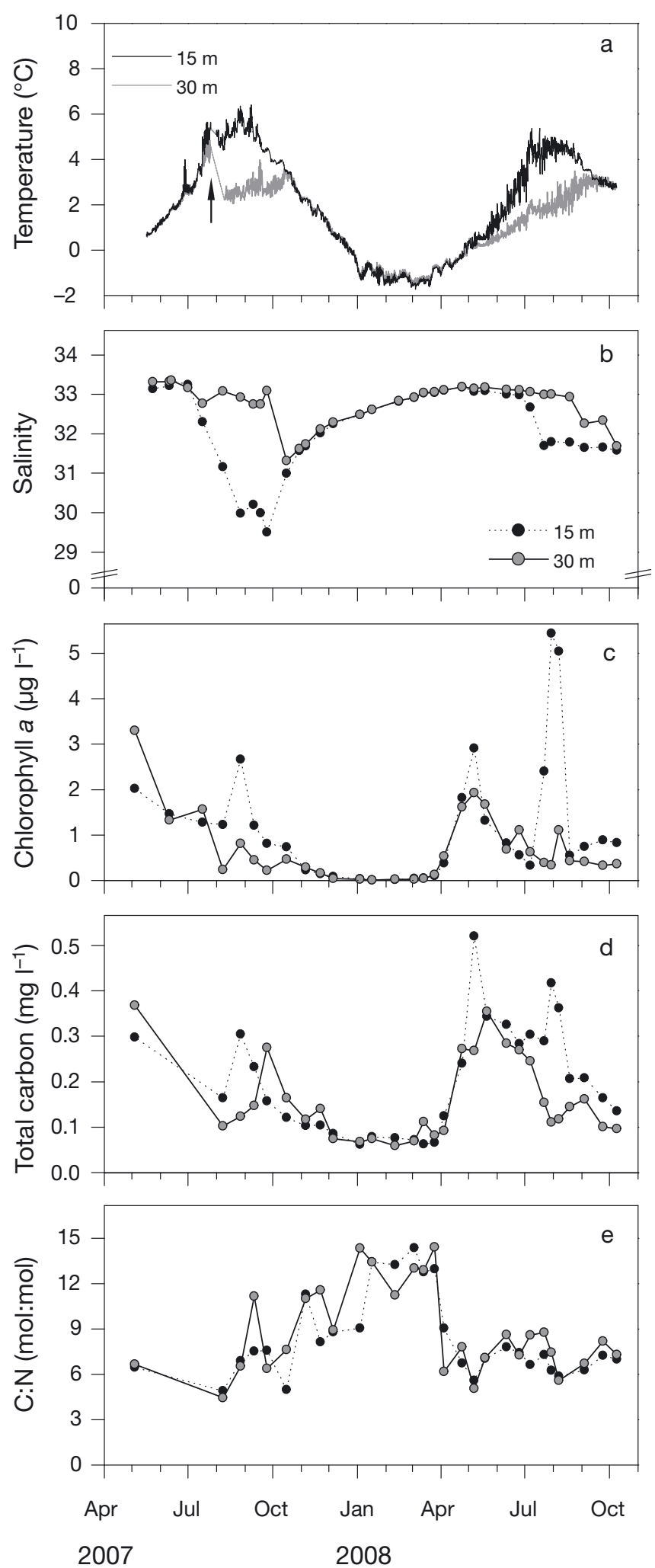

Fig. 2. Variation in environmental parameters at the study site at 15 and $30 \mathrm{~m}$ depth from May 2007 to October 2008. (a) Temperature $\left({ }^{\circ} \mathrm{C}\right)$, (b) salinity (PSU), (c) chl a $\left(\mu \mathrm{g} \mathrm{l}{ }^{-1}\right),(\mathrm{d})$ total particulate carbon (TPC) $\left(\mathrm{mg} \mathrm{l}^{-1}\right)$, (e) C:N ratio (mol:mol). Arrow in Fig. 3a marks the time of relocation of scallops tion criterion (AIC) using a forward selection method. The relative model probability was examined with Akaike weights $\left(W_{i}\right)$ (Johnson \& Omland 2004). Models were tested for autocorrelation structure $(\operatorname{lag}=1)$. To examine the robustness of the results to the fact that data were sampled at 2 different depths, dummy variables for depth were added to the model. Data were analyzed using SAS statistical software (SAS Institute 2006).

\section{RESULTS}

\section{Environmental parameters}

During the initial study period from May to August 2007, it became clear that water column properties at 15 and $30 \mathrm{~m}$ depth at the deployment site did not differ as much as we expected. We concluded that the site was too exposed to give the intended variation in environmental parameters between depths, and as a consequence we relocated the lantern nets to a more protected site in Kobbefjord (Fig. 1), where a pycnocline had established during spring and summer.

Temperature. The annual temperature cycle at 15 and $30 \mathrm{~m}$ depth is illustrated in Fig. 2a, which shows an amplitude ranging from $-1.5^{\circ} \mathrm{C}$ at both depths in February and March to a maximum of 4.5 to $6^{\circ} \mathrm{C}$ at $15 \mathrm{~m}$ depth and $\sim 3^{\circ} \mathrm{C}$ at $30 \mathrm{~m}$ depth in late summer and early autumn. The time of the relocation of lantern nets from the exposed site to the more protected site in Kobbefjord is easily recognized; in August 2007 the temperature at the 2 depths was very similar indicating a well-mixed water column. The sudden decrease in temperature at $30 \mathrm{~m}$ marks the relocation to the Kobbefjord site where the water column was more stratified.

Salinity. Seasonal dynamics in the freshwater runoff from land caused differences in salinity between 15 and $30 \mathrm{~m}$ depth during summer. The lowest salinity was observed in summer 2007. During the entire study period, salinity ranged from 29.5 to 33.5 (Fig. 2b).

Chl a. A phytoplankton spring bloom was observed in May 2007 and May 2008, when chl a concentrations peaked at 2 to $3 \mu \mathrm{g} \mathrm{l}^{-1}$ followed by declining concentrations at both 15 and $30 \mathrm{~m}$ depth. A second bloom occurred in August-September at $15 \mathrm{~m}$ in both years, while chl a concentrations at $30 \mathrm{~m}$ declined continuously during the late summer to a minimum of $\sim 0.01 \mu \mathrm{g}$ $\mathrm{l}^{-1}$ during winter (Fig. 2c).

TPC. The concentration of TPC at 15 and $30 \mathrm{~m}$ depth in Kobbefjord ranged between $\sim 0.06$ and $\sim 0.5 \mathrm{mg} \mathrm{l}^{-1}$ in winter and spring-summer, respectively. Distinct peaks were observed in spring at both depths in 2007 and 2008 (Fig. 2d). 
C:N. There was a clear seasonal cycle in the C:N ratio in Kobbefjord. From April to October, C:N values were relatively low, ranging from $\sim 5$ to $\sim 8.5$ at both depths. Values increased throughout autumn and winter to a maximum of $\sim 14.5$, until they steeply decreased again at the onset of the phytoplankton growing season (Fig. 2e).

\section{Tag retention and mortality}

The highest tag loss and mortality of scallops was, not unexpectedly, observed in the recovery period following collection and tagging. Of the 752 tagged scallops 6 $(0.8 \%)$ had lost their tags during the first $\sim 2.5 \mathrm{mo}$ after deployment. The number of dead specimens in the same period was $10(1.3 \%)$, after which both mortality and tag loss remained at a constantly low level until the end of the experiment. During the entire study period of $17 \mathrm{mo}, 14$ tags were lost and 19 individuals died.

\section{Overall patterns in biomass and growth}

The general relations between $\mathrm{SH}(\mathrm{mm})$ and tissue DM (g) are given below, and illustrated in Fig. 3a:

$$
\begin{gathered}
\log _{\mathrm{e}}\left(\mathrm{DM}_{\text {pred somatic }}\right)=-11.45+3.034 \log _{\mathrm{e}}(\mathrm{SH}) \\
\left(\mathrm{n}=502, \mathrm{R}^{2}=0.93, \mathrm{p}<0.001\right) \\
\log _{\mathrm{e}}\left(\mathrm{DM} \mathrm{M}_{\text {pred gonad }}\right)=-28.27+6.773 \log _{\mathrm{e}}(\mathrm{SH}) \\
\left(\mathrm{n}=496, \mathrm{R}^{2}=0.85, \mathrm{p}<0.001\right) \\
\log _{\mathrm{e}}\left(\mathrm{DM} \mathrm{M}_{\text {pred total }}\right)=-12.23+3.269 \log _{\mathrm{e}}(\mathrm{SH}) \\
\left(\mathrm{n}=502, \mathrm{R}^{2}=0.94, \mathrm{p}<0.001\right)
\end{gathered}
$$

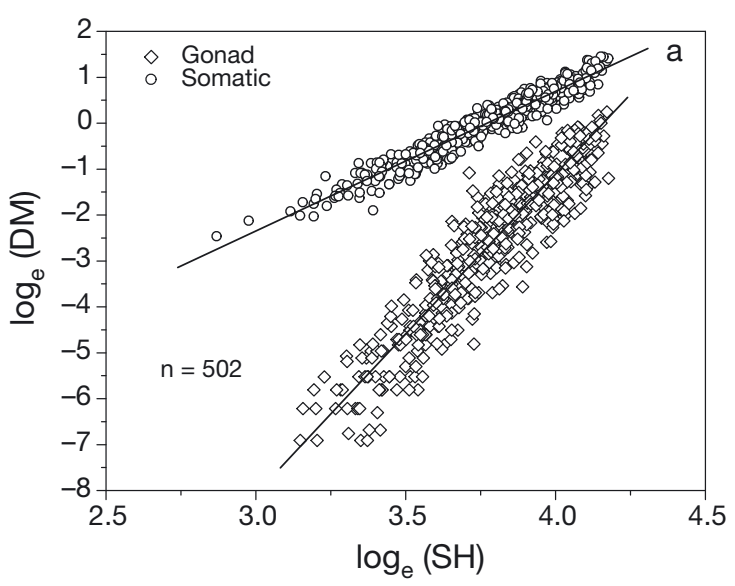

The specialized von Bertalanffy growth function established from SID from August 2007 to August 2008 was:

$$
\begin{gathered}
\mathrm{SH}_{\text {pred }}=94\left\{1-\exp \left(-5.9 \times 10^{-3} t\right)\right\} \\
\left(\mathrm{n}=259, \mathrm{R}^{2}=0.96, \mathrm{p}<0.001\right)
\end{gathered}
$$

According to this function, the asymptotic $\mathrm{SH}_{\infty}$ was $94 \mathrm{~mm}$ and the growth coefficient, $K$, was $5.9 \times 10^{-3}$ $\mathrm{d}^{-1}$. The first derivative, which describes shell growth rate, $\hat{G}_{\mathrm{s}}\left(\mathrm{mm} \mathrm{d}^{-1}\right)$ as a function of $\mathrm{SH}$ (Fig. 3b), was:

$$
\hat{G}_{\mathrm{s}}=5.9 \times 10^{-3} \mathrm{SH}\left(\frac{94}{\mathrm{SH}}-1\right)
$$

Overall relations between $\mathrm{SH}$ and mass growth rate, $G_{\mathrm{m}}$, were established by maximizing the joint likelihood. The resulting growth model parameters are listed in Table 1, and show decreasing growth rate with increasing size $(b<0)$. All 3 models gave heteroscedastic variation $(z \neq 0)$. The gonad mass growth rate model showed increasing $\mathrm{SD}$ with $\mathrm{SH}(z>0)$, while the somatic growth rate model showed decreasing SD with increasing $\mathrm{SH}(z<0)$. In combination, this resulted in a slightly negative $z$ value in the total mass growth rate model (Fig. 4).

These general models for biomass, shell growth rate, and mass growth rate as a function of $\mathrm{SH}$ provided a basis for describing the seasonal dynamics of these parameters.

\section{Seasonal shell growth variation}

Both size groups showed the same principal seasonal pattern in shell growth rate, with minimum values

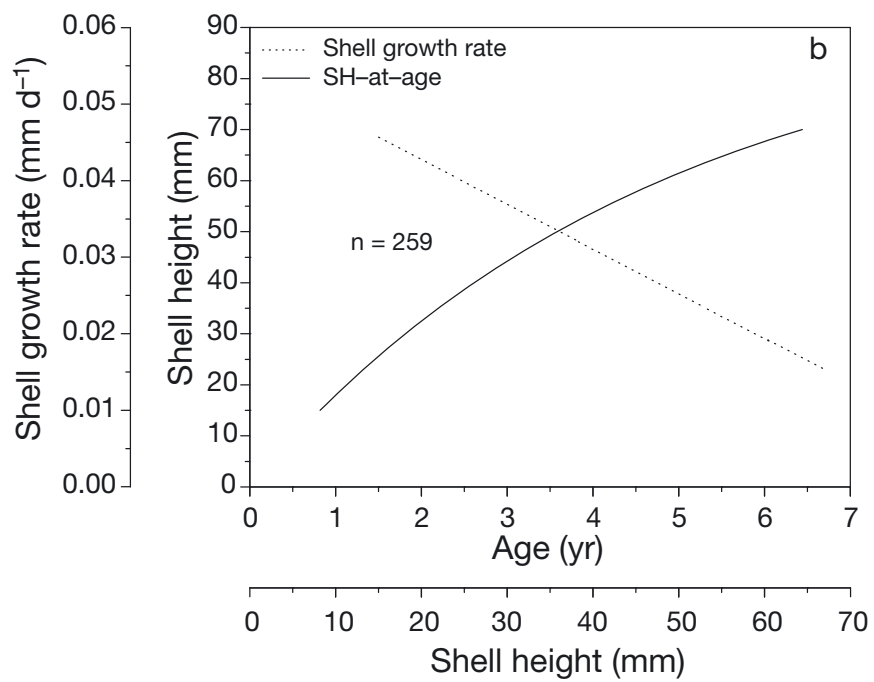

Fig. 3. Chlamys islandica. (a) General relations between dry mass (DM, g) and shell height (SH, mm) for somatic and gonad tissues. (b) von Bertalanffy growth function $\mathrm{SH}_{\text {pred }}=94\left\{1-\exp \left(-5.9 \times 10^{-3} t\right)\right\}$ estimated from size-increment-data (SID), and its first derivative, showing the average daily shell growth rate as a function of $\mathrm{SH}$ 
Table 1. Chlamys islandica. Parameters of the regression of mass growth rate on shell height (SH) as described in Eqs. (8), (9) \& (10). Parameters were obtained by maximizing joint likelihood. Illustrated in Fig. 4

\begin{tabular}{|c|c|c|c|c|c|c|c|}
\hline \multirow{2}{*}{$\begin{array}{l}\text { Mass growth } \\
\text { model }\end{array}$} & \multicolumn{4}{|c|}{ - Parameters } & \multicolumn{3}{|c|}{ Statistics } \\
\hline & $a$ & $b$ & $q$ & z & $\mathrm{n}$ & $\mathrm{R}^{2}$ & $\mathrm{p}$ \\
\hline Somatic & 0.0213 & -0.0476 & 0.0124 & -0.3440 & 5186 & 0.16 & $<0.0001$ \\
\hline Gonad & 0.0353 & -0.0438 & 0.0023 & 0.3815 & 5186 & 0.08 & $<0.0001$ \\
\hline Total & 0.0197 & -0.0443 & 0.0131 & -0.3635 & 5186 & 0.16 & $<0.0001$ \\
\hline
\end{tabular}

peak growth in spring, but differed in late summer and early autumn, with higher mass growth rates at $15 \mathrm{~m}$ than at $30 \mathrm{~m}$ depth. A single spawning event indicated by highly negative gonad $\mathrm{GI}_{\mathrm{m}}$ values independent of size group and depth, was registered in June-July 2008. Thus, scallops, which were immature at the beginning at the experiment (Group 1) were apparently maturing at the end of the study period. from January to April and peaking in autumn from August to November (Fig. 5). However, scallops at $30 \mathrm{~m}$ depth had lower maximum shell growth rates than those at $15 \mathrm{~m}$ depth. This difference was most pronounced in 2007. For scallops in Group 2, the seasonal cycle in shell growth rate was interrupted by an abrupt decline in June-July 2008 concurrent with spawning (see 'Results - Seasonal variation in mass growth').

\section{Seasonal variation in BMI}

The ANCOVA tests did not reveal any statistically significant effects of $\mathrm{SH}$ or $\mathrm{SH} \times$ sampling date on $\mathrm{BMI}$ ( $p>0.05)$, indicating that season did not affect the slope, $b$ in Eq. (5), and that BMI could be regarded as size-independent in all seasons. The annual cycle in the somatic biomass index, $\mathrm{BMI}_{\text {somatic }}$ of Chlamys islandica was characterized by a fast increase during spring from April to July-August followed by a more stable period during autumn. Winter was characterized by a slower but steady decrease until early April (Fig. 6a,b). The variability of $\overline{\mathrm{BMI}}_{\text {gonad }}$ values at the specific dates was higher than for $\overline{\mathrm{BMI}}_{\text {somatic }}$ but it was still evident that BMI of gonad and somatic tissues did not follow the same seasonal pattern. $\overline{\mathrm{BMI}}_{\text {gonad }}$ at $30 \mathrm{~m}$ depth was relatively constant throughout the study period, while at $15 \mathrm{~m}$ depth we observed an increase in $\overline{\mathrm{BMI}}_{\text {gonad }}$ from January 2008 to July 2008, where it declined abruptly (Fig. 6c,d). This sudden decline was also reflected in $\overline{\mathrm{BMI}}_{\text {total, }}$ which, apart from that, followed a pattern very similar to $\overline{\mathrm{BMI}}_{\text {somatic }}$ (Fig. 6e,f). $\overline{\mathrm{BMI}}$ s were generally at a slightly higher level at $15 \mathrm{~m}$ than at $30 \mathrm{~m}$ depth. This difference was most pronounced in autumn (October-November).

\section{Seasonal variation in mass growth}

We observed clear seasonal variation in $\mathrm{GI}_{\mathrm{m}}$ of Chlamys islandica. Values generally peaked in AprilJune and were lowest from November to March (Fig. 7). Mass growth rates at $15 \mathrm{~m}$ and $30 \mathrm{~m}$ were similar during

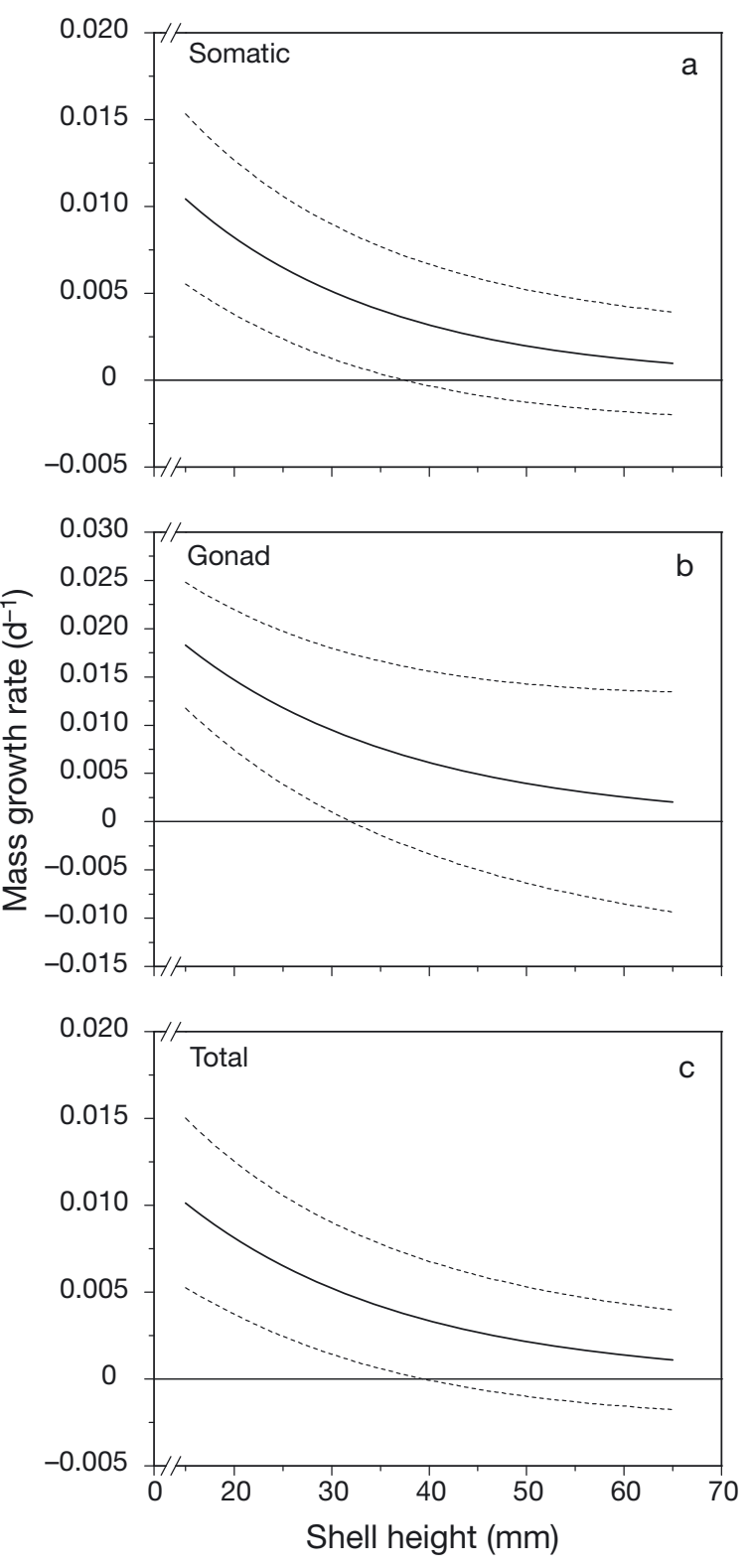

Fig. 4. Chlamys islandica. Overall relations between mass growth rate, $\hat{G}_{\mathrm{m}}$ (somatic, gonad, and total) and shell height (SH). Dotted lines indicate standard deviation (SD). See Table 1 for parameters of the functions 


\section{Coupling of mass growth rate to seasonal environmental variation}

We corrected for the considerable biomass loss resulting from spawning in early July 2008 by assuming $\mathrm{BMI}_{\text {gonad }}$ to have the same values as observed in the June sampling, thus removing the effect of spawn-
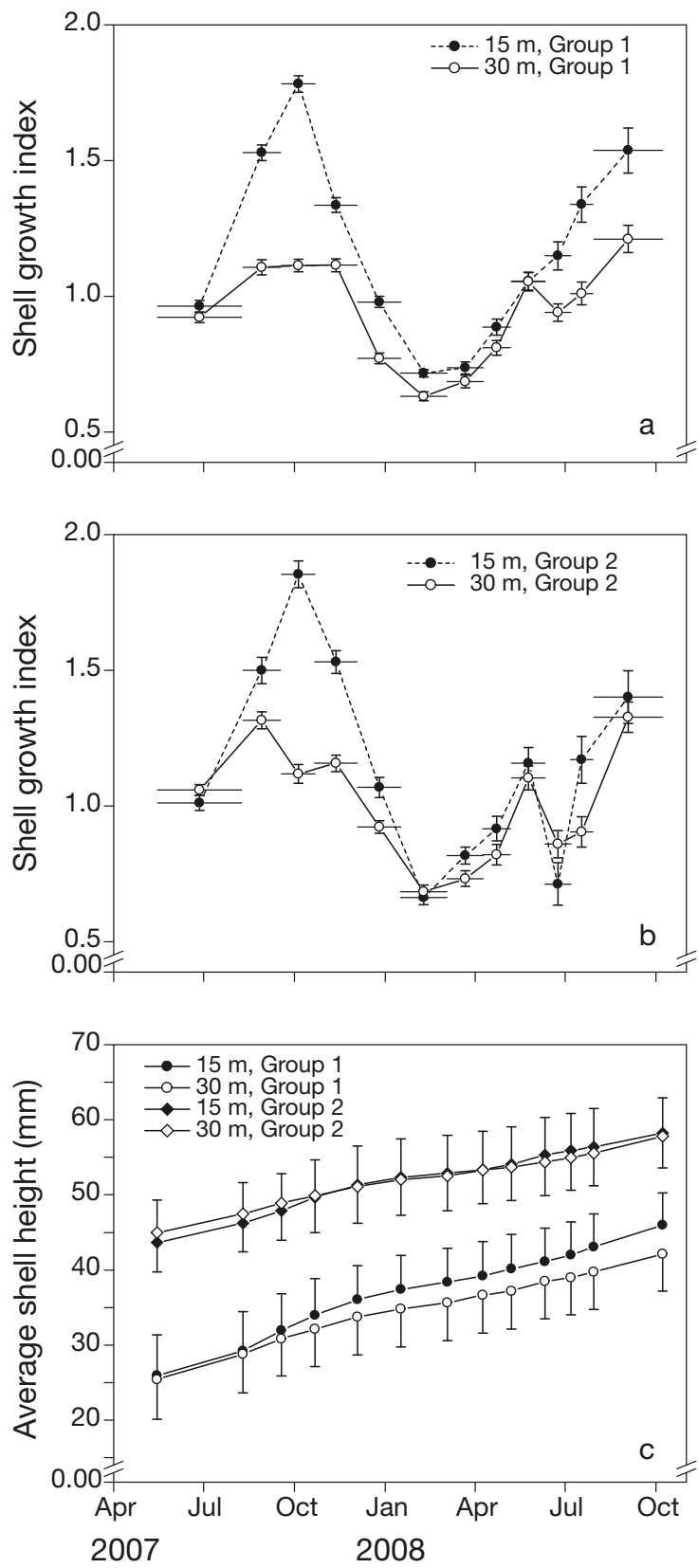

Fig. 5. Chlamys islandica. Seasonal variation in shell growth index, $\mathrm{GI}_{\mathrm{s}}$ at 15 and $30 \mathrm{~m}$ for the 2 size groups (a) Group 1 and (b) Group 2. Vertical error bars indicate SD. Horizontal bars specify the period for which the average $\mathrm{GI}_{\mathrm{s}}$ values were estimated. (c) Average shell height $(\mathrm{SH})( \pm \mathrm{SD})$ of the 4 separate groups throughout the study period ing on the estimates of $\mathrm{GI}_{\mathrm{m}}$. We did this to exclude any loss of biomass not directly related to the balance between energy intake and metabolic costs. Though not optimal, this approach prevented any bias of data and allowed us to focus on the effects of key environmental drivers on the energy balance of scallops.

Chl a was found to have a strong and statistically significant ( $\mathrm{p}<0.0001$ ) positive effect on total $\mathrm{GI}_{\mathrm{m}}$ of Chlamys islandica (Model I, AIC $=80.4, \mathrm{r}^{2}=0.66$ ). However, this model indicated a statistically significant autocorrelation structure of the residuals $(p<0.05)$. Adding temperature as a second independent variable resulted in an increase in the model fit (Model II, AIC = 76.1, $\mathrm{R}^{2}=0.69$ ), indicating a statistically significant negative effect of increasing temperature on the mass growth rate of scallops ( $p<0.001)$. We obtained the best growth model fit by including $\mathrm{C}: \mathrm{N}$, which had a statistically significant negative effect $(p<0.001)$ on the mass growth rate (Model III, AIC $=72.1, W_{i}=0.55$, $\left.\mathrm{R}^{2}=0.71\right)$. Neither TPC, chl $a$ :TPC, nor salinity had any statistically significant effect $(p>0.05)$ and increased the AIC (models not shown). Likewise, no interaction terms increased model fit significantly. We found no significant autocorrelation in Models II and III ( $p$ > 0.05 ) and the non-significant autoregressive parameters were backward eliminated. Dummy variables for depth were added to Model III to test the robustness of the model. The effect of depth was not statistically significant ( $p=0.88)$, and neither size nor the statistical significance of the coefficients was affected by adding dummies to the model (Model IV, $\mathrm{AIC}=72.9, W_{i}=0.37$, $\left.\mathrm{R}^{2}=0.72\right)$ (Table 2).

\section{DISCUSSION}

\section{Mass growth rate in relation to environmental variation}

The seasonal cycles of temperature and food availability (chl a, C:N, TPC) were partly decoupled in SW Greenland. The spring phytoplankton bloom went on at very low temperature $\left(\sim 0^{\circ} \mathrm{C}\right)$, followed by an increase in temperature and a late summer bloom at $15 \mathrm{~m}$ depth. This made it possible to distinguish between the effects of these factors on the growth rate of Chlamys islandica. Seasonal variation in the total mass growth rate of $C$. islandica correlated statistically significantly to food availability (chl $a$ and $\mathrm{C}: \mathrm{N}$ ) and temperature. The forward selection procedure of regression models indicated that the concentration of chl $a$ in the surrounding water column was the most important explanatory parameter for the variation in mass growth rate of $C$. islandica (Table 2). Together with the fact that the effect of seasonal variation in $C: N$ 

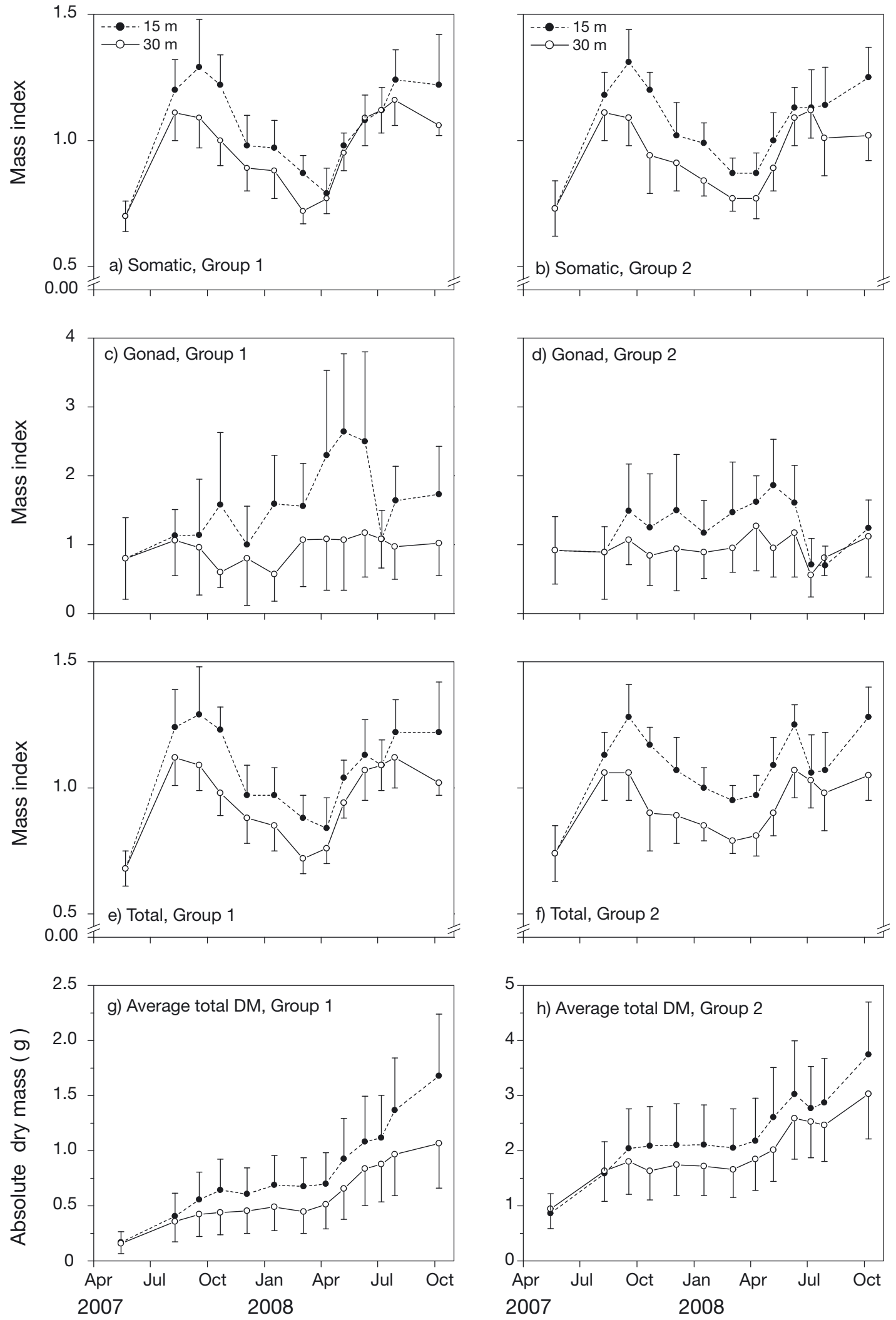

Fig. 6. Chlamys islandica. (a-f) Seasonal variation in average biomass index, $\overline{\mathrm{BMI}}$ (somatic, gonad, and total) at $15 \mathrm{and} 30 \mathrm{~m}$ for the 2 size groups (Group 1 and Group 2), respectively. $(g, h)$ Temporal development in average individual biomass in absolute values for Groups 1 and 2 at 15 and $30 \mathrm{~m}$, respectively, throughout the study period. Vertical error bars indicate SD 

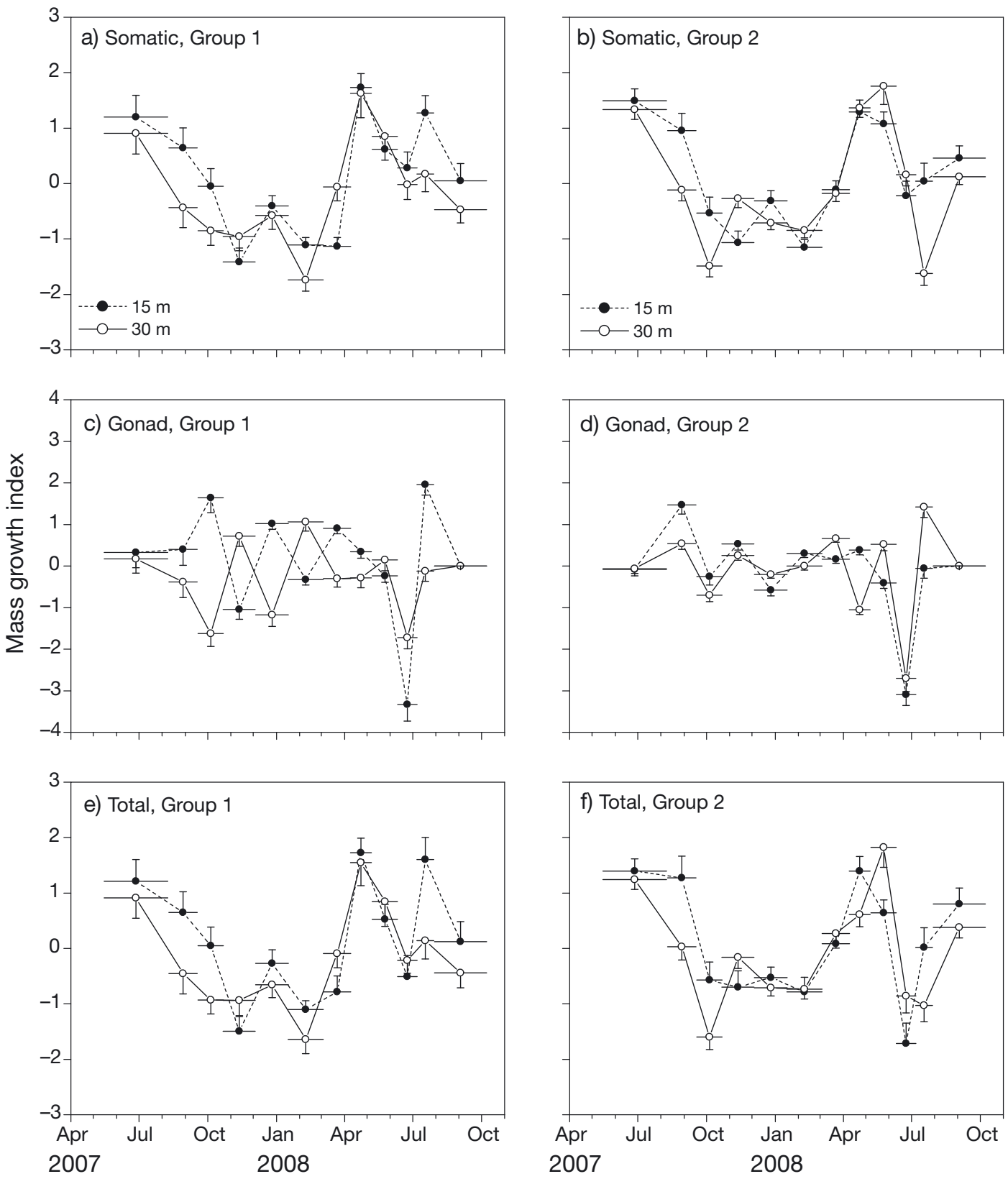

Fig. 7. Chlamys islandica. Seasonal variation in average mass growth index, $\mathrm{GI}_{\mathrm{m}}$ (somatic, gonad, and total) at 15 and $30 \mathrm{~m}$ for the 2 size groups (Groups 1 and 2) respectively. Vertical error bars indicate the SD. Horizontal bars specify the period for which the average $\mathrm{GI}_{\mathrm{m}}$ values have been estimated

ratio was statistically significant, and that TPC was not, this result indicated that the availability of high-quality food items such as phytoplankton is essential for the mass growth rate of scallops. Other potential sources of food, such as sedimentary, resuspended, or allochtonous matter being partly degenerated, were apparently not utilized efficiently and were therefore of secondary importance in the study area. However, from Fig. 2c it seems highly likely that chl $a$ and TPC covary, and this potential co-variation might account for the lack of significant effects of TPC using the forward selection procedure. Actually TPC correlated significantly to $\mathrm{GI}_{\mathrm{m}}\left(\mathrm{p}<0.01, \mathrm{R}^{2}=0.42\right)$; however chl a was selected as the better predictor (Table 2), and in the following steps TPC came out insignificant. In any case, although TPC did not come out as statistically significant in the growth model, low-quality food items might be of crucial importance during starvation in the winter period in order to maintain or minimize the loss of biomass. 
Table 2. Coefficients $( \pm \mathrm{SE})$ and Akaike's information criterion (AIC) of the forward selected regression models for the effect of environmental parameters on mass growth (total $\mathrm{GI}_{\mathrm{m}}, \mathrm{n}=$ 48) of Chlamys islandica. $W_{i}$ (AIC) $=$ Akaike weight (model probability). Non-significant parameters (ns) were backward eliminated (except for control variables). ${ }^{*} \mathrm{p}<0.05,{ }^{* *} \mathrm{p}<0.01$. Model III was the best-fit model with a model probability $\left(W_{i}\right)$ of $55 \%$. -: not included in model

\begin{tabular}{|c|c|c|c|c|}
\hline & \multicolumn{4}{|c|}{ _Model } \\
\hline & I & II & III & IV \\
\hline Intercept & $\begin{array}{c}-0.68^{* *} \\
(0.18)\end{array}$ & $\begin{array}{c}-0.71^{* *} \\
(0.12)\end{array}$ & ns & ns \\
\hline $\mathrm{Chl} \mathrm{a}\left(\mu \mathrm{g} \mathrm{l^{-1 }}\right)$ & $\begin{array}{c}0.93^{* *} \\
(0.16)\end{array}$ & $\begin{array}{l}1.25^{* *} \\
(0.13)\end{array}$ & $\begin{array}{l}1.13^{* *} \\
(0.11)\end{array}$ & $\begin{array}{l}1.14^{* *} \\
(0.12)\end{array}$ \\
\hline Temperature $\left({ }^{\circ} \mathrm{C}\right)$ & - & $\begin{array}{c}-0.16^{* *} \\
(0.05)\end{array}$ & $\begin{array}{c}-0.19^{* *} \\
(0.04)\end{array}$ & $\begin{array}{c}-0.19^{* *} \\
(0.05)\end{array}$ \\
\hline C:N (mol:mol) & - & - & $\begin{array}{c}-0.06^{* *} \\
(0.01)\end{array}$ & $\begin{array}{c}-0.06^{* *} \\
(0.01)\end{array}$ \\
\hline \multicolumn{5}{|l|}{ Autocorrelation } \\
\hline Lag 1 & $\begin{array}{l}0.37^{*} \\
(0.15)\end{array}$ & ns & ns & - \\
\hline \multicolumn{5}{|l|}{ Control variables } \\
\hline $15 \mathrm{~m}$ & - & - & - & $-0.02^{\mathrm{ns}}$ \\
\hline $30 \mathrm{~m}$ & - & - & - & 0.00 \\
\hline $\mathrm{R}^{2}$ & 0.657 & 0.687 & 0.713 & 0.717 \\
\hline $\mathrm{AIC}$ & 80.4 & 76.1 & 72.1 & 72.9 \\
\hline$W_{i}(\mathrm{AIC})$ & 0.009 & 0.074 & 0.549 & 0.368 \\
\hline
\end{tabular}

Our results are in accordance with Thorarinsdóttir (1994) who suggested that the growth season for Chlamys islandica in Iceland coincided with the period of high phytoplankton levels. Likewise, Harrington (1987) suggested that large-scale variations in the growth of the venerid bivalve genus Protothaca in the NE Pacific were caused by differences in the length of the period during which organisms could feed. This also agrees with a laboratory study of a high-Arctic clam Hiatella arctica at sub-zero temperature concluding that energy assimilation increased with chl a concentrations until an optimum at $8 \mu \mathrm{g} \mathrm{l}^{-1}$ chl $a$, which was never attained in its natural environment (Sejr et al. 2004). In comparison, maximum chl a concentrations found at our study site were 3 to $5 \mu \mathrm{g} \mathrm{l}^{-1}$ during blooms. Another proxy for the nutritional value of seston, the ratio between inorganic and organic particles (PIM:POM), was suggested to affect the energy balance of $C$. islandica in northern Norway by reducing the absorption efficiency at high fractions of PIM (Vahl 1980, Wallace \& Reinsnes 1985). This indicated that $C$. islandica might be susceptible to elevated inputs of inorganic particles from land, and to resuspension of bottom material, which has been suggested for other bivalve species (Riisgård 2001, Ellis et al. 2002, Safi et al. 2007). In temperate and tropical areas the seasonal and short-term variations in metabolism and clearance rate, shell growth, condition, or mass production of bivalves have been studied intensively. Effects of current speed and wave exposure, particle size, as well as salinity changes have been suggested in some studies (Kirby-Smith 1972, Roman et al. 1999, Sobral \& Widdows 2000, Steffani \& Branch 2003). However, a number of studies have indicated that spatial or temporal variation in food availability, expressed either as the amount of chlorophyll, the organic or energetic content of seston, or total seston, is a major factor regulating the production of scallops (Macdonald \& Thompson 1985, Lodeiros et al. 1998, Pilditch \& Grant 1999, Navarro et al. 2000, Hunauld et al. 2005). The importance of different proxies for the quality or quantity of food seems to vary depending on site and seston characteristics and on species. Other studies have reported either positive or negative effects of increasing temperature on the energy balance of bivalves within the normal range of habitat temperature (Witbaard et al. 1997, Han et al. 2008, Beukema et al. 2009). The growth rate of the bay scallop Argopecten irradians was independent of chl a concentrations (0.5 to $5.5 \mu \mathrm{g}$ $\mathrm{l}^{-1}$ ) at low temperatures for its natural habitat (10 to $\left.16^{\circ} \mathrm{C}\right)$, but became increasingly correlated with chl a levels at higher temperatures $\left(22\right.$ to $\left.28^{\circ} \mathrm{C}\right)$ (Kirby-Smith \& Barber 1974), reflecting the increased metabolic costs at higher temperatures. In combination, the available studies support the idea of interrelated effects of temperature and resource availability on the energy balance of bivalves and other ectotherms (e.g. Clarke 2003). It is well documented that elevated temperature increases the metabolic rate of ectotherms living within their thermal limits $\left(Q_{10}=2\right.$ to 4$)$ (Gillooly et al. 2001), and pectinids are no exception (Heilmayer et al. 2004). Elevated physiological rates can be assumed to affect the filtering capacity of bivalves positively (e.g. Petersen et al. 2003), thus increasing the potential consumption of food and the capacity for growth. On the other hand, in a food-limited environment (absolute or temporal) elevated physiological rates might turn into an energetic disadvantage, because the increased energetic demands cannot be completely compensated for by higher energy intake (Pilditch \& Grant 1999, Clarke 2003, Clarke \& Fraser 2004). C. islandica in SW Greenland is well within the thermal limits of this species (Jonasson et al. 2004). Thus, the negative effect of increasing temperature on the mass growth rate of $C$. islandica, as suggested in the mass growth model in this study (Table 2), supports the indication of resource limitation at the study site in SW Greenland. Hence, within the existing range of resource quality and quantity and temperature, the capacity for consumption or growth of $C$. islandica is either never realized or only attained for short periods of time. Instead, low water temperature $\left(\sim 0^{\circ} \mathrm{C}\right)$ provides the basis for 


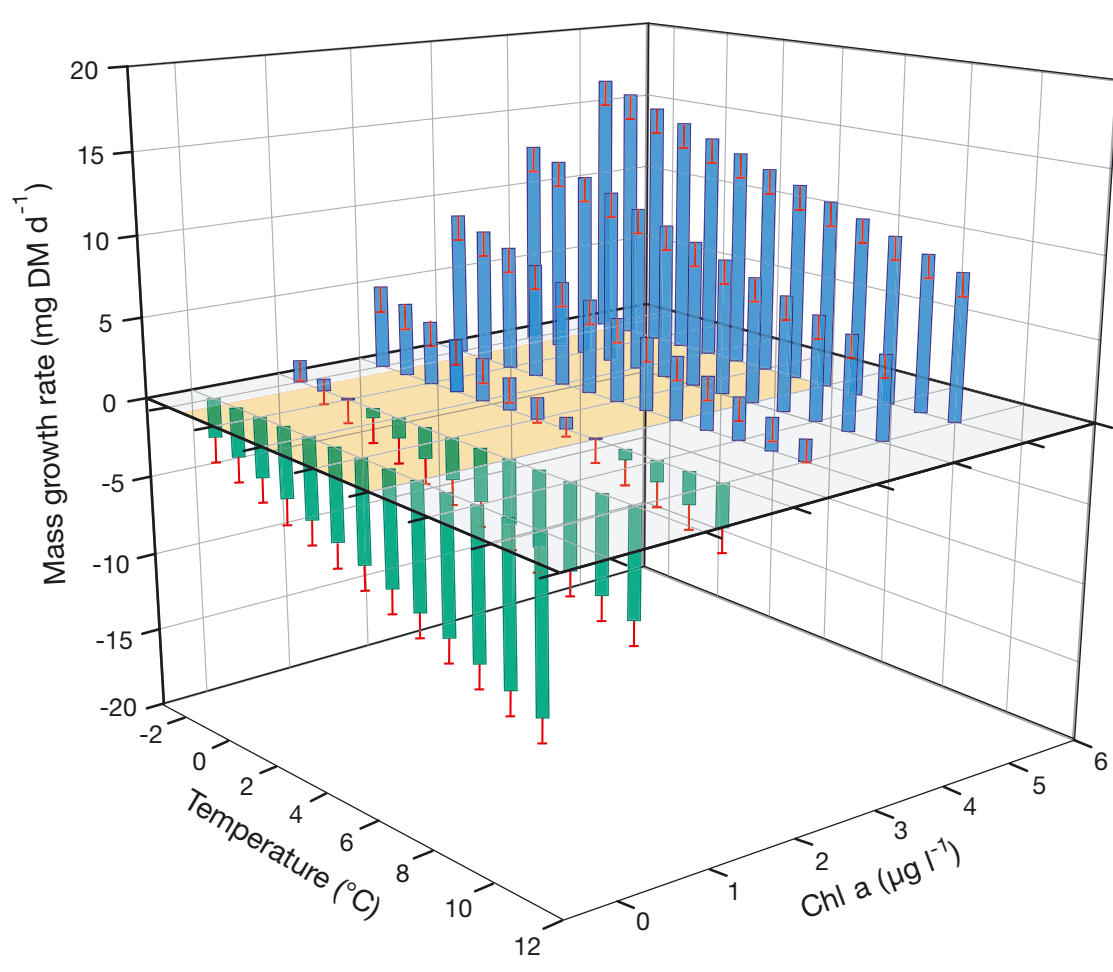

Fig. 8. Chlamys islandica. Absolute mass growth rate of an individual of $1 \mathrm{~g}$ dry mass (DM) (42 mm shell height, $\mathrm{SH}$ ) plotted against temperature and chl $a$ at $\mathrm{C}: \mathrm{N}=6.6$ (Redfield ratio). Red bars indicate the negative effect of the $\mathrm{C}: \mathrm{N}$ ratio increasing to 14 . Yellow shaded area shows the range of environmental parameters in the study area during 2007 and 2008

low metabolic costs of $C$. islandica during the starvation period in winter and for maximizing the growth efficiency during the spring phytoplankton bloom. Therefore, potential phytoplankton blooms during the warmer summer period, as observed in 2008, cannot be converted into mass growth as efficiently as in spring as a consequence of higher basic metabolic costs. This is illustrated with absolute values of mass growth rate in Fig. 8, which describes visually how small changes in the seasonal dynamics of temperature and food conditions affect the energy budget of $C$. islandica. The yellow shaded area indicates the range of parameters given in the study area during 20072008. However, C. islandica is able to exist successfully under warmer conditions than the ones recorded in SW Greenland, e.g. in Norway and Iceland (Vahl 1978, Thorarinsdóttir 1994). For scallops there is no indication of an uncoupling of basal metabolism and temperature on a geographical scale (Heilmayer et al. 2004). Thus, increased metabolic costs in response to elevated temperature should be compensated for by higher energy assimilation, ultimately resulting in reduced growth efficiency at higher temperatures, which is implicit in our mass growth model and in agreement with a comparative analysis of scallop species living at different temperature regimes (Heilmayer et al. 2004). On an evolutionary time-scale marine ectotherms are probably not selected for their high growth efficiency as much as for their absolute rate of new tissue production (Clarke 1993, Pörtner et al. 2005). However, it is evident that high energy efficiency is an effective way of maximizing absolute growth in a resource-limited environment like our study site in SW Greenland.

In conclusion, it is reasonable to suggest that, within the ranges of environmental parameters given in this study, the growth capacity of Chlamys islandica is determined by temperature. However, this growth capacity cannot be realized due to food limitations, which makes food fluctuations the most important factor for scallop growth in sub-Arctic Greenland.

Still, it is important for us to stress that the present study solely considers the effect of seasonal variation in environmental parameters on the mass growth rate of Chlamys islandica, not geographical variation nor long-term changes. The extent to which our results can be considered representative of other spatial and temporal scales as well as of other macrobenthic species is still to be tested. We are convinced, however, that the changes in seasonal dynamics of physical as well as biological structures are the basis for potential long-term changes of ecosystems, which in itself emphasizes the perspective of the present study.

\section{Comparison of wild and suspended scallops}

The overall shell growth pattern of the cultured scallops, as expressed through the von Bertalanffy growth function, differed from the wild population from 50 to $60 \mathrm{~m}$ depth in Kobbefjord (Blicher et al. 2009). Scallops growing in culture at 15 and $30 \mathrm{~m}$ depth have a markedly faster average annual growth rate and were able to reach a $\mathrm{SH}$ of $60 \mathrm{~mm}$ within $\sim 5 \mathrm{yr}$, while it takes more than $10 \mathrm{yr}$ to reach the same size in the local wild population (Blicher et al. 2009), which is similar to Svalbard and other localities in west Greenland. Wild populations in northern Norway, Canada, and Iceland reached $60 \mathrm{~mm} \mathrm{SH}$ in 6 to $7 \mathrm{yr}$ (Pedersen 1994 and references therein). Markedly increased growth rates of Chlamys islandica in 
suspended cultures at shallow depth compared to a natural population have been observed previously in Iceland (Thorarinsdóttir 1994). Even though our mass growth model (Table 2) is based on data for suspended scallops, we believe that growth of scallops living under natural conditions on the seabed is affected by the same exogenous parameters as growth of scallops in a suspended culture. Based on the growth rate model we suggest that spatial differences in food availability and temperature are major causes of growth variation in scallops. In the present study, the suspended scallops were placed at depths near the subsurface peak in algal biomass observed during spring and autumn (Mikkelsen et al. 2008). In addition, wild scallops might episodically be faced with the challenge of resuspension of bottom material containing high amounts of inorganic material. However, in the natural environment in Greenland the abundance of $C$. islandica is low at depths $<20 \mathrm{~m}$ (Pedersen 1994, Blicher et al. 2009), which indicates that other factors than the ones investigated in the present study prevent them from spreading to this seemingly favourable habitat. The distribution pattern may be affected by: (1) substrate-dependent settling indirectly related to depth; (2) depth-related differences in epi-growth (e.g. barnacles, macroalgae, sponges) with an effect on mortality on a longer timescale than our study; (3) other types of inter-specific competition or predation. Firstly, it is well-established that certain substrates are more favourable for settling of C. islandica than others (Harvey et al. 1993, Arsenault \& Himmelman 1996a). In the study area $C$. islandica seems to prefer settling on coarse substrates or shell gravel (Pedersen 1994, Blicher et al. 2009), and juveniles are often found attached to the inner side of old scallop shells (M. E. Blicher pers. obs., Arsenault \& Himmelman 1996b). Therefore, depthrelated changes in the sea bed structure might affect the distribution of $C$. islandica. Secondly, it has been suggested that epi-growth can be responsible for relatively high mortalities of scallops in otherwise favourable habitats (Lodeiros et al. 1998). In the wild population of $C$. islandica at 50 to $60 \mathrm{~m}$ depth in Kobbefjord we observed high epi-growth of primarily barnacles on the shells of some of the largest (>75 mm $\mathrm{SH}$ ) and presumably oldest individuals, potentially affecting their fitness. However, the scallops suspended at 15 and $30 \mathrm{~m}$ depth were not affected by epi-growth to any large extent, and differences between depths were not clearly detectable, even though filamentous macroalgae were more abundant on the lantern nets at $15 \mathrm{~m}$ compared to $30 \mathrm{~m}$ depth (not quantified). A third possibility is that scallops are prevented from spreading to a more favourable habitat by shallow-living competitors. In a previous study in Kobbefjord it was found that the sea urchin Strongylocentrotus droebachiensis dominated the epibenthic community down to $20 \mathrm{~m}$ depth. Thus, sea urchins and scallops were to a large extent separated vertically (Blicher et al. 2009). S. droebachiensis, which is very common in Greenland (Blicher et al. 2007), can be an aggressive grazer on a variety of diets and produces barrens (Himmelman et al. 1983, Meidel \& Scheibling 1999, Balch \& Scheibling 2000, Gagnon et al. 2004), and might be a co-factor affecting the distribution of C. islandica. Also the crab Hyas areneus, which is common in the study area, can be an important predator on juvenile $C$. islandica, and field experiments have shown that the vulnerability of scallops to predators is highly affected by substrate and the possibility of finding refuge (e.g. crevices, dead shells) (Arsenault \& Himmelman 1996b)

The factors controlling the depth distribution of scallops are still unresolved, however. Even though we may have left out some potentially important factors affecting the overall success of Chlamys islandica in the ecosystem, the coupling of growth to food availability and temperature is still valid and can be considered important within the ecological niche of this species. Our conclusions are strengthened by the fact that the experiment was carried out in the natural environment, thus increasing the relevance on a broader ecological scale.

\section{The use of proxies for seasonal mass growth}

The present study also provides the opportunity to evaluate the use of biomass indices and shell growth as proxies for seasonal variation in production. These and other parameters have been used in a number of studies as alternatives to measures of actual soft tissue production (e.g. Wallace \& Reinsnes 1985). Though not always tested, the suitability of these proxies varies and is highly dependent on the experimental set-up, e.g. the temporal scale (Wo et al. 1999). Our study of Chlamys islandica indicates a mismatch between tissue production and shell growth $\left(\mathrm{R}^{2}=0.01, \mathrm{p}=0.49\right.$, $\mathrm{n}=48$ ), which has been observed in other polar ectotherms (Peck et al. 2000), potentially resulting in a decreasing biomass index (BMI) during a period with relatively constant individual biomass (Fig. 6e-h). We observed the highest tissue growth rates in May, while shell growth did not peak until October (Figs. 5 \& 7), albeit showing similar tendencies with regard to differences between depths on an annual scale. This might be interpreted as a lag between tissue production and shell growth. However, a positive effect of temperature on the rate of elemental uptake into the shell of bivalves has been shown (Strasser et al. 2008). Sea- 
sonal variation in shell growth rate of $C$. islandica in this study was positively correlated to temperature $\left(\mathrm{R}^{2}=0.63, \mathrm{p}<0.01, \mathrm{n}=48\right)$. However, at present it is uncertain whether this was a result of a causal relationship. In any case, neither seasonal variation in shell growth nor that in biomass index of $C$. islandica would be reliable proxies for the actual soft tissue production.

\section{CONCLUDING REMARKS}

Different concepts have been proposed regarding the relative importance of temperature and food availability for the population dynamics of polar marine ectotherms (Krogh 1916, Clarke 2003, Pörtner et al. 2005). Based on ecosystem monitoring studies and laboratory experiments, food limitation has been suggested to be a general phenomenon for Arctic macrobenthos (Ambrose \& Renaud 1995, Sejr et al. 2004, Grebmeier et al. 2006, Blicher et al. 2009). However, this apparent resource dependency has not been described in detail. In the present study, we observed a high degree of seasonal and spatial variation in the growth of Chlamys islandica, which was strongly linked to variation in food availability as well as temperature, confirming the initial hypothesis that this species is resource limited in SW Greenland, and that increased temperature through its effect on metabolic costs reduces growth efficiency. Thus, our study provides detailed information on the degree of seasonality and the processes controlling benthic production in the Arctic. The expected future shifts in annual temperature cycle, and changes in sea ice dynamics and in freshwater run-off potentially affecting the level of primary production in the Arctic area, are likely to affect the seasonal energetics of $C$. islandica, and consequences may be long-term. $C$. islandica might benefit from future climate changes in high-Arctic areas where reduced sea ice cover will increase primary production markedly, but water temperature will remain constantly low $\left(\sim 0^{\circ} \mathrm{C}\right)$. However, in warmer sub-Arctic areas the energetic outcome is expected to be more dependent on the timing between phytoplankton blooms and the seasonal temperature dynamics, which is difficult to predict at present. In conclusion, our results emphasize the importance of understanding ecological relationships on a short-term scale in order to be able to interpret long-term changes.

Acknowledgements. Thanks to A. Haxen for linguistic corrections. We thank L. Heilmann and F. Heinrich for technical assistance. The authors were financially supported by the Commission for Scientific Research in Greenland (KVUG), the Ministry of Culture, Education and Churches (KIIP), and the Aage V. Jensen Charity Foundation. The project has received financial support from the Danish Energy Agency as part of the climate support program to the Arctic and is a contribution to the Nuuk Basic program.

\section{LITERATURE CITED}

Ambrose W, Renaud P (1995) Benthic response to water column productivity patterns: evidence for benthic-pelagic coupling to the northeast water polynya. J Geophys Res 100:4411-4421

> Arrigo KR, Dijken GV, Pabi S (2008) Impact of shrinking Arctic ice cover on marine primary production. Geophys Res Lett 35:L19603, doi: 10.1029/2008GL035028

> Arsenault DJ, Himmelman JH (1996a) Ontogenic habitat shifts of the Iceland scallop, Chlamys islandica (Müller, 1776), in the northern Gulf of St Lawrence. Can J Fish Aquat Sci 53:884-895

Arsenault DJ, Himmelman JH (1996b) Size-related changes in vulnerability to predators and spatial refuge use by juvenile Iceland scallops Chlamys islandica. Mar Ecol Prog Ser 140:115-122

Balch T, Scheibling R (2000) Temporal and spatial variability in settlement and recruitment of echinoderms in kelp beds and barrens in Nova Scotia. Mar Ecol Prog Ser 205:139-154

> Beukema JJ, Dekker R, Jansen JM (2009) Some like it cold: populations of the tellinid bivalve Macoma balthica (L.) suffer in various ways from a warming climate. Mar Ecol Prog Ser 384:135-145

Blicher ME, Rysgaard S, Sejr MK (2007) Growth and production of sea urchin Strongylocentrotus droebachiensis in a high-Arctic fjord, and growth along a climatic gradient (64 to $\left.77^{\circ} \mathrm{N}\right)$. Mar Ecol Prog Ser 341:89-102

Blicher ME, Sejr MK, Rysgaard S (2009) High carbon demand of dominant macrozoobenthic species indicates their central role in ecosystem carbon flow in a sub-Arctic fjord. Mar Ecol Prog Ser 383:127-140

Brey T (2001) Population dynamics in benthic invertebrates. A virtual handbook. Version 01.2. http://www.thomasbrey.de/science/virtualhandbook

Brockington S, Clarke A (2001) The relative influence of temperature and food on the metabolism of a marine invertebrate. J Exp Mar Biol Ecol 258:87-99

Clarke A (1993) Seasonal acclimatization and latitudinal compensation in metabolism: Do they exist? Funct Ecol 7: $139-149$

> Clarke A (2003) Costs and consequences of evolutionary temperature adaption. Trends Ecol Evol 18:573-581

> Clarke A, Fraser K (2004) Why does metabolism scale with temperature? Funct Ecol 18:243-251

> Clarke A, Johnston N (1999) Scaling of metabolic rate with body mass and temperature in teleost fish. J Anim Ecol 68: 893-905

Conover RJ, Huntley M (1991) Copepods in ice-covered seas - distribution, adaptations to seasonally limited food, metabolism, growth patterns and life cycle strategies in polar seas. J Mar Syst 2:1-41

$>$ Dagg M, Benner R, Lohrenz S, Lawrence D (2004) Transformation of dissolved and particulate materials on continental shelves influenced by large rivers: plume processes. Cont Shelf Res 24:833-858

Ellis J, Cummings V, Hewitt J, Thrush S, Norkko A (2002) Determining effects of suspended sediment on condition of a suspension feeding bivalve (Atrina zelandica): results of a survey, a laboratory experiment and a field transplant experiment. J Exp Mar Biol Ecol 267:147-174 
Gagnon P, Himmelman J, Johnson L (2004) Temporal variation in community interfaces: kelp-bed boundary dynamics adjacent to persistent urchin barrens. Mar Biol 144: 1191-1203

Gillooly JF, Brown JH, West GB, Savage VM, Charnov EL (2001) Effects of size and temperature on metabolic rate. Science 293:2248-2251

Grebmeier JM, Cooper LW, Feder HM, Sirenko BI (2006) Ecosystem dynamics of the Pacific-influenced northern Bering and Chukchi Seas in the Amerasian Arctic. Prog Oceanogr 71:331-361

> Han KN, Lee SW, Wang SY (2008) The effect of temperature on the energy budget of the Manila clam, Ruditapes philippinarum. Aquac Int 16:143-152

Hanna E, Huybrechts P, Steffen K, Cappelen J and others (2008) Increased runoff from melt from the Greenland ice sheet: a response to global warming. J Clim 21:331-341

Harrington RJ (1987) Skeletal growth histories of Protothaca staminea (Conrad) and Protothaca grata (Say) throughout their geographic ranges, northeastern Pacific. Veliger 30: 148-158

> Harvey M, Bourget E, Miron G (1993) Settlement of Iceland scallop Chlamys islandica spat in response to hydroids and filamentous red algae: field observations and laboratory experiments. Mar Ecol Prog Ser 99:283-292

Heide-Jorgensen MP, Dietz R, Laidre KL, Richard P, Orr J, Schmidt HC (2003) The migratory behaviour of narwhals (Monodon monoceros). Can J Zool Rev Can Zool 81: 1298-1305

Heilmayer O, Brey T, Pörtner H (2004) Growth efficiency and temperature in scallops: a comparative analysis of species adapted to different temperatures. Funct Ecol 18:641-647

Heilmayer O, Honnen C, Jacob U, Chiantore M, CattaneoVietti R, Brey T (2005) Temperature effects on summer growth rates in the Antarctic scallop, Adamussium colbecki. Polar Biol 28:523-527

> Himmelman J, Cardinal A, Bourget E (1983) Community development following removal of urchins, Strongylocentrotus droebachiensis, from the rocky subtidal zone of the St. Lawrence Estuary, eastern Canada. Oecologia 59:27-39

> Hunauld P, Velez A, Jordan N, Himmelman JH, Morales F, Freites L, Lodeiros CJ (2005) Contribution of food availability to the more rapid growth of the scallop, Euvola ziczac (Pteroida, Pectinidae) in bottom than in suspended culture. Rev Biol Trop 53:455-461

Johannessen OM, Bengtsson L, Miles MW, Kuzmina SI and others (2004) Arctic climate change: observed and modelled temperature and sea-ice variability. Tellus Ser A Dyn Meteorol Oceanol 56:328-341

Johnson JB, Omland KS (2004) Model selection in ecology and evolution. Trends Ecol Evol 19:101-108

> Jonasson JP, Thorarinsdottir GG, Eiriksson H, Marteinsdottir G (2004) Temperature tolerance of Iceland scallop, Chlamys islandica (OF Müller) under controlled experimental conditions. Aquac Res 35:1405-1414

Kirby-Smith WW (1972) Growth of the bay scallop: the influence of experimental water currents. J Exp Mar Biol Ecol 8:7-18

Kirby-Smith WW, Barber TT (1974) Suspension-feeding aquaculture systems: effects of phytoplankton concentration and temperature on growth of the bay scallop. Aquaculture 3:135-145

Krogh A (1916) The respiratory exchange of animals and man. Longmans, Green and Co., London

Larsen RJ, Marx ML (2005) An introduction to mathematical statistics and its applications, 4th edn. Prentice Hall, London
Lebreton J, Burnham K, Clobert J, Anderson D (1992) Modelling survival and testing biological hypothesis using marked animals: a unified approach with case studies. Ecol Monogr 62:67-118

Lindsay RW, Zhang J, Schweiger A, Steele M, Stern H (2009) Arctic sea ice retreat in 2007 follows thinning trend. J Clim 22:165-176

Lodeiros C, Rengel J, Freites L, Morales L, Himmelman J (1998) Growth and survival of the tropical scallop Lyropecten (Nodipecten) nodosus maintained in suspended culture at three depths. Aquaculture 165:41-50

Macdonald BA, Thompson RJ (1985) Influence of temperature and food availability on the ecological energetics of the giant scallop Placopecten magellanicus. I. Growthrates of shell and somatic tissue. Mar Ecol Prog Ser 25: 279-294

McPhee MG, Proshutinsky A, Morison JH, Steele M, Alkire MB (2009) Rapid change in freshwater content of the Arctic Ocean. Geophys Res Lett 36:L10602 doi: 10.1029/ 2009GL037525

> Meidel S, Scheibling R (1999) Effects of food type and ration on reproductive maturation and growth of the sea urchin Strongylocentrotus droebachiensis. Mar Biol 134:155-166

Mikkelsen DM, Rysgaard S, Mortensen J, Retzel A and others (2008) Nuuk basic: the marine basic programme 2007 , Danish Polar Centre, Danish Agency for Science, Technology and Innovation, Ministry of Science, Technology and Innovation, Copenhagen

- Narvarte M (2003) Growth and survival of the tehuelche scallop Aquipecten tehuelchus in culture. Aquaculture 216: $127-142$

> Navarro J, Leiva G, Martinez G, Aguilera C (2000) Interactive effects of diet and temperature on the scope for growth of the scallop Argopecten purpuratus during reproductive conditioning. J Exp Mar Biol Ecol 247:67-83

Parsons TR, Maita Y, Lalli CM (1984) A manual for chemical and biological methods for seawater analysis. Pergamon Press, Toronto

> Peck L, Colman J, Murray A (2000) Growth and tissue mass cycles in the infaunal bivalve Yoldia eightsi at Signy Island, Antarctica. Polar Biol 23:420-428

Pedersen S (1994) Population parameters of the Iceland scallop (Chlamys islandica (Müller)) from west Greenland. J Northwest Atl Fish Sci 16:75-87

Petersen JK, Sejr MK, Larsen JEN (2003) Clearance rates in the Arctic bivalves Hiatella arctica and Mya sp. Polar Biol 26:334-341

> Peterson BJ, Holmes RM, McClelland JW, Vorosmarty CJ and others (2002) Increasing river discharge to the Arctic Ocean. Science 298:2171-2173

Pilditch C, Grant J (1999) Effect of temperature fluctuations and food supply on the growth and metabolism of juvenile scallops (Placopecten magellanicus). Mar Biol 134: 235-248

> Pörtner HO, Storch D, Heilmayer O (2005) Constraints and trade-offs in climate-dependent adaption: energy budgets and growth in a latitudinal cline. Sci Mar 69:271-285

- Riisgård HU (2001) On measurement of filtration rates in bivalves - the stony road to reliable data: review and interpretation. Mar Ecol Prog Ser 211:275-291

> Roman G, Campos M, Acosta C, Cano J (1999) Growth of the queen scallop (Aequipecten opercularis) in suspended culture: influence of density and depth. Aquaculture 178: $43-62$

Ross K, Thorpe J, Norton T, Brand T (2001) An assessment of some methods for tagging the great scallop, Pecten maximus. J Mar Biol Assoc UK 81:975-977 
Rysgaard S, Nielsen TG (2006) Carbon cycling in a high-arctic marine ecosystem-Young Sound, NE Greenland. Prog Oceanogr 71:426-445

Rysgaard S, Nielsen TG, Hansen BW (1999) Seasonal variation in nutrients, pelagic primary production and grazing in a high-Arctic coastal marine ecosystem, Young Sound, Northeast Greenland. Mar Ecol Prog Ser 179:13-25

Rysgaard S, Vang T, Stjernholm M, Rasmussen B, Windelin A, Kiisholm S (2003) Physical conditions, carbon transport, and climate change impacts in a northeast Greenland fjord. Arct Antarct Alp Res 35:301-312

Safi KA, Hewitt JE, Talman SG (2007) The effect of high inorganic seston loads on prey selection by the suspensionfeeding bivalve, Atrina zelandica. J Exp Mar Biol Ecol 344: 136-148

Sejr MK, Christensen PB (2007) Growth, production and carbon demand of macrofauna in Young Sound, with special emphasis on the bivalves Hiatella arctica and Mya truncata. In: Rysgaard S, Glud RN (eds) Carbon cycling in Arctic marine ecosystems: case study Young Sound, Vol 58. Meddelelser om Grønland, Bioscience, Copenhagen

Sejr MK, Petersen JK, Jensen KT, Rysgaard S (2004) Effects of food concentration on clearance rate and energy budget of the Arctic bivalve Hiatella arctica (L) at subzero temperature. J Exp Mar Biol Ecol 311:171-183

Sobral P, Widdows J (2000) Effects of increasing current velocity, turbidity and particle-size selection on the feeding activity and scope for growth of Ruditapes decussatus from Ria Formosa, southern Portugal. J Exp Mar Biol Ecol 245:111-125

Editorial responsibility: Otto Kinne, Oldendorf/Luhe, Germany
Steffani C, Branch G (2003) Growth rate, condition, and shell shape of Mytilus galloprovincialis: responses to wave exposure. Mar Ecol Prog Ser 246:197-209

Strasser CA, Mullineaux LS, Thorrold SR (2008) Temperature and salinity effects on elemental uptake in the shells of larval and juvenile softshell clams Mya arenaria. Mar Ecol Prog Ser 370:155-169

Thorarinsdóttir G (1994) The Iceland scallop, Chlamys islandica (OF Müller), in Breidafjord, west Greenland. III. Growth in suspended culture. Aquaculture 120:295-303

Vahl O (1978) Seasonal changes in oxygen consumption of the Iceland scallop (Chlamys islandica (O.F. Müller)) from $70^{\circ} \mathrm{N}$. Ophelia 17:143-154

> Vahl O (1980) Seasonal variations in seston and in the growth rate of the Iceland scallop, Chlamys islandica (OF Müller) from Balsfjord, 70 N. J Exp Mar Biol Ecol 48:195-204

Wallace JC, Reinsnes TG (1985) The significance of various environmental parameters for growth of the Iceland scallop, Chlamys islandica (Pectinidae) in hanging culture. Aquaculture 44:229-242

- Wassmann P, Slagstad D, Riser C, Reigstad M (2006) Modelling the ecosystem dynamics of the Barents Sea including the marginal ice zone. II. Carbon flux and interannual variability. J Mar Syst 59:1-24

> Witbaard R, Franken R, Visser B (1997) Growth of juvenile Arctica islandica under experimental conditions. Helgol Meeresunters 51:417-431

Wo KT, Lam PKS, Wu RSS (1999) A comparison of growth biomarkers for assessing sublethal effects of cadmium on a marine gastropod, Nassarius festivus. Mar Pollut Bull 39: $165-173$

Submitted: July 16, 2009; Accepted: February 8, 2010 Proofs received from author(s): May 5, 2010 